\title{
Особливості епідеміології коронавірусної інфекції SARS-CoV-2 на рівні сімейної медицини
}

\author{
Т.Г. Подгорна', В.С. Бірюков ${ }^{2}$, О.Г. Шаповалов', Н.Б. Кірпічова'
}

'Дитячий консультативно-діагностичний центр, Одеса, Україна

${ }^{2}$ Одеський національний медичний університет, Одеса, Україна

\begin{abstract}
Анотація. Проведено ретроспективний аналіз історій хвороби пацієнтів із 42 сімей (59 дітей віком 2-18 років і 72 батьків) із підтвердженою інфекцією SARS-CoV-2. У досліджуваного контингенту дітей перебіг захворювання був без ураження легень зі звичайним симптомокомплексом гострого респіраторного вірусного захворювання і не потребував стаціонарного лікування, тоді як у 59 дорослих членів сімей діагностували COVID-19-асоційовану пневмонію, яка зумовила необхідність у госпіталізації. Отримані дані можуть вказувати на потенційно маніфестну роль дітей як резервуара й основного переносника інфекції SARS-CoV-2 в умовах великого міста, про що свідчила хвиля захворюваності серед батьків через 6,08土0,26 дня, при цьому у батьків відзначали виражене ураження бронхолегеневої системи. Підтверджено обтяжливий вплив шкідливих звичок (тютюнопаління), наявності преморбідної/ поліморбідної патології на тяжкість клінічної картини у дорослих хворих. Соціальне дистанціювання при домашній ізоляції у рамках сім'ї демонструвало низьку ефективність, а висока вартість ПлР-тестування негативно впливала на терміни встановлення діагнозу.

Ключові слова: SARS-CoV-2, сімейна медицина, COVID-19 у дітей та дорослих, роль дітей у передачі SARS-CoV-2.
\end{abstract}

\section{Вступ}

Станом на 18.03.2020 р., за даними Центру системних наук та інженерії (Center for Systems Science and Engineering) Університету Джона Хопкінса (Johns Hopkins University), США, у світі зареєстровано 121256160 підтверджених випадків COVID-19. щоденні уточнювальні графіки незаперечно демонструють зростання пандемії, викликаної коронавірусом SARS-CoV-2, і незначні успіхи систем охорони здоров'я більшості країн у подоланні цієї небезпеки. 3 моменту появи перших повідомлень 3 Уханю, Китай, випадки захворювання зареєстровані на усіх континентах [1-3].

При зовнішній схожості захворювання COVID-19 з епідемією грипу, однією з важливих відмінностей $\epsilon$ темп передачі інфекції. Середня тривалість інкубаційного періоду (час від моменту зараження до виникнення симптомів) і час генерації (час між зараженням однієї людини і зараженням іншої) при грипі менший. За оцінками, час генерації при COVID-19 становить 5-6 днів, тоді як при грипі - 3. Це означає, що грип може поширюватися швидше, ніж COVID-19 [4]. Крім того, ключовим елементом у поширенні грипу $\epsilon$ передача інфекції протягом перших 3-5 днів хвороби і, можливо, до дебюту симптомів захворювання. Незважаючи на відомості, що у деяких хворих із COVID-19 вірусовиділення може виникати за 24-48 год до розвитку симптомів, в даний час, ймовірно, воно не відіграє такої важливої ролі у поширенні інфекції [5]. За останніми даними, репродуктивне число, тобто кількість осіб, яких може заразити один хворий, при COVID-19 знаходиться у діапазоні 2-2,5, що вище, ніж при грипі [4].

Враховуючи більш низьку санітарно-гігієнічну грамотність дітей та їх виражену соціальну активність, вивчення епідеміологічних особливостей коронавірусної інфекції серед дитячого населення вважається актуальним.

Мета дослідження - вивчення ролі дітей в епідеміології коронавірусної інфекції SARS-CoV-2 у сім'ях в умовах великого міста з розвиненою інфраструктурою інституту сімейних лікарів.

\section{Об'єкт і методи дослідження}

Робота має дизайн ретроспективного дослідження за даними вивчення амбулаторних карт пацієнтів Центру первинної медико-санітарної допомоги, м. Одеса.

Проведена вибірка історій захворювань пацієнтів та їх сімей, які проживають у центрі Одеси, - міста 3 населен- ням >1 млн жителів, що обслуговуються сімейними лікарями на основі контрактних відносин. Договірні відносини зареєстровані з 322 сім'ями, що налічують 1614 осіб, у тому числі 476 дітей віком 0-18 років. Охоплено другий пік поширення коронавірусної інфекції у м. Одеса за період вересень-грудень 2020 р. Протягом 4 міс кількість первинних звернень 3 приводу захворювань верхніх дихальних шляхів у дітей становила 264 випадки, що на 95 (56,21\%) більше, ніж за аналогічний період 2019 р. У 59 (22,35\%) дітей, що захворіли, із 42 сімей (у деяких сім'ях захворювало по дві дитини) підтверджено діагноз коронавірусної інфекції. Вікова категорія хворих дітей 2-18 років.

\section{Результати}

При первинному зверненні в усіх дітей відзначали типові симптоми гострої респіраторної вірусної інфекції (ГРВІ) з клінічною картиною ринофарингіту, тонзилофарингіту і ларинготрахеїту. У $7(11,86 \%)$ дітей при огляді встановлено діагноз «гострий бронхіт». У 8 (13,56\%) дітей відзначали супутні кишкові розлади.

У загальному аналізі крові у 46 (77,97\%) дітей відзначали лейкопенію, у 41 (69,49\%) - лімфоцитоз, у 47 (79,66\%) - моноцитоз, у 46 (77,97\%) - помірно прискорену швидкість осідання еритроцитів. Усі діти лікувалися амбулаторно за стандартною методикою й отримували симптоматичну і противірусну терапію. 13 (20,03\%) дітям, у яких в аналізі крові відзначали виражений лейкоцитоз з нейтрофільозом і високу швидкість осідання еритроцитів, проводили антибіотикотерапію. Через 7-9 днів від початку терапії всі діти одужали, що підтверджено як клінічними, так і лабораторними даними. Ускладнень не виявлено.

Вимоги лікаря щодо щоденного моніторингу температури тіла, кашлю або задишки у дітей виконувалися батьками у 100\% випадків. Однак рекомендації щодо носіння масок вдома і дотримування соціальної дистанції (2 м) виконані лише у 2 (3,39\%) сім'ях з дітьми підліткового віку. Домашній карантин дотримувалися у 34 (57,63\%) сім'ях.

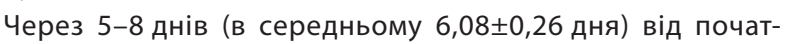
ку звернення батьків з дітьми до сімейного лікаря почалися виклики онлайн з боку хворих батьків: 1 батько звернувся на 4-й, 23 - на 5-й, $22-$ на 6-й, $18-$ на 7-й і 8 - на 8-й день $(\mathrm{n}=72)$. Зазначена епідеміологічна динаміка відображена на рисунку. 
Рисунок Епідеміологічні особливості розповсюдження коронавірусної інфекції на сімейному рівні

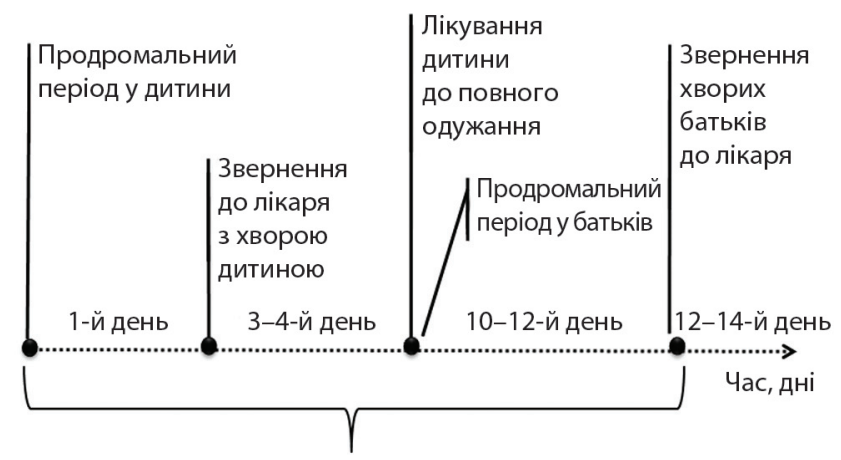

Тривалість заразного періоду в сім'ї 3 хворою на коронавірусну інфекцію дитиною

На відміну від дітей, у батьків, крім звичайного симптомокомплексу гострих респіраторних вірусних інфекцій (ГРВІ), відзначали високу температуру тіла ( $\left.>38^{\circ} \mathrm{C}\right)$, виражений головний біль, підвищену втому, погіршення настрою, тривогу, депресію, зниження (аж до зникнення) нюху і смаку, нав'язливий непродуктивний кашель. Призначені тести полімеразної ланцюгової реакції (ПЛР) на COVID-19 та комп'ютерна томографія легень. В усіх 72 батьків, що звернулися, підтверджена коронавірусна інфекція. Наявність інтерстиціальної пневмонії з феноменом «матового скла» виявлена у 53 батьків, з них 38 (71,70\%) чоловіків і 15 (28,30\%) жінок. Курцями були усі хворі чоловіки та 1/4 жінок. Таким чином, у чоловіків частіше відзначали легеневі ураження (співвідношення чоловіки:жінки - 2,5:1). Усі ці пацієнти направлені у стаціонар.

Після виявлення коронавірусної інфекції батьків усі діти 3 цих сімей обстежені на COVID-19. В усіх 59 дітей перенесений COVID-19 підтверджений різними аналізами. ПлРдіагностика виконана тільки одній 16-річній дитині і показала позитивний результат. У 47 дітей проведена діагностика на наявність специфічних антитіл до коронавірусу — імуноглобуліни М i G (якісна реакція), у 11 дітей - тільки імуноглобулін G. Біохімічний аналіз крові включав C-реактивний білок, D-димер, фібриноген, інтерлейкін-6 (5 дітей), печінкові тести (аланінамінотрансфераза, аспартатамінотрансфераза), глюкоза в крові. Біохімічні аналізи не були порушені.

\section{Обговорення}

Питання про роль дитячого населення у передачі коронавірусної інфекції не вирішене остаточно. Дані цього дослідження не підтверджують поширену попередню інформацію про те, що діти меншою мірою схильні до зараження, ніж дорослі, і частіше заражаються від дорослих. Разом з тим їх відносять до групи ризику, поряд із вагітними, особами похилого віку, пацієнтами з коморбідними і поліморбідними захворюваннями та імунокомпрометованими особами. У разі COVID-19 згідно з поточним розумінням захворювання факторами ризику тяжкого перебігу $\epsilon$ похилий вік і наявність фонових захворювань $[4,6]$. Отримані нами дані підтверджують, що найбільш вразливою групою населення $\epsilon$ пацієнти із хронічними захворюваннями, а також те, що до захворювання більше схильні чоловіки, що палять, ніж жінки.

Сімейному лікарю при складанні рекомендацій необхідно враховувати декілька факторів. Віруси нестійкі у зовнішньому середовищі. За попередньою інформацією, вірус може виживати на поверхнях лише протягом кількох годин. Звичайні дезінфікуючі засоби можуть вбити вірус, виключаючи можливість зараження людей. Віруси миттєво гинуть при температурі $>56^{\circ} \mathrm{C}$, руйнуються під дією хлороформу, формаліну, етилового спирту або ефіру [6]. Ця інформація повинна виробити позитивне й оптимістичне ставлення у членів сім'ї у період карантину щодо можливості припинення вірусної інфекції у межах квартири.
Інфекція поширюється повітряно-крапельним шляхом через вдихання розпорошених у повітрі у процесі кашлю або чхання крапель з вірусом, а також з потраплянням вірусу на поверхні з подальшим занесенням в очі, ніс або рот. Особиста гігієна дітей молодшого віку підтримується виключно батьками, і через це ризик фекально-орального або контактного зараження дітей раннього віку надзвичайно високий.

Необхідно визнати, що розрахунок важливого епідеміологічного індексу «загального тягаря COVID-19» за допомогою даних, відображених в документації сімейного лікаря, досить відносний. Причина в тому, що медичні працівники діагностують і реєструють лише частину респіраторних інфекцій. Недавні дослідження, проведені у США і країнах Європи, показали, що реальний рівень попереднього контакту з SARS-CoV-2, підтверджений серопозитивністю, перевищує частоту зареєстрованих випадків приблизно у $\geq 10$ разів [7-9]. У такому разі можемо припустити наявність зараження не тільки у 72 батьків, що звернулися до лікаря, але й у близько 700 безсимптомних носіїв інфекції.

Основний шлях передачі SARS-CoV-2 від людини до людини - аерогенний [10]. Така можливість інфікування при поїздці у громадському транспорті, колективних зборах і зустрічах специфічна для дорослих людей. 3 іншого боку, носіння маленьких дітей на руках, ігри з ними, використання спільного посуду, обійми і поцілунки становлять не меншу загрозу зараження. Цей елемент сімейних відносин традиційний, і потреба в ньому вище ризиків, про які говорить сімейний лікар.

Дотепер немає єдиної думки про причини такого стрімкого поширення SARS-CoV-2. Вірусні молекули РНК можуть передаватися на великі відстані повітряним шляхом (шляхом вдихання частинок меншого розміру, ніж краплі, які залишаються у повітрі з плином часу та на відстані). Однак життєздатність цих РНК-молекул і здатність викликати захворювання швидко вичерпується. Тому цей спосіб підтримки пандемії $\epsilon$ спірним, як і теза про небезпеку заражених поверхонь предметів [11, 12]. Все це свідчить про відсутність тотожності між виявленням вірусної РНК і «живим» вірулентним вірусом.

Зазначимо, і це важливо в роботі сімейного лікаря, що активність вірусів SARS-CoV-2 пролонгується в погано вентильованих приміщеннях. Прагнення батьків захистити дітей від протягів часто порушує цей гігієнічний принцип, що підвищує ризик їх власного зараження через побутові предмети $[13,14]$.

Таким чином, проведене нами дослідження показало, що у 42 сім'ях, які перебувають під наглядом сімейного лікаря, проживають у центрі міста з добре розвиненою інфраструктурою, хворі на коронавірусну інфекцію діти в період вересень-грудень 2020 р. становили близько $1 / 5$ кількості дітей, які звернулися з приводу ГРВІ. Симптоматика хворих на коронавірусну інфекцію дітей не відрізнялася від сезонного поширення ринофарингіту, ларинготрахеїту, тонзилофарингіту та ентеровірусної інфекції. Усі клінічні випадки мали середній ступінь тяжкості й після отримання стандартної для ГРВІ терапії всі діти одужали протягом 1-2-го тижня.

Діти стали носіями інфекції у своїх сім'ях, про що свідчить

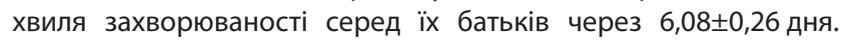
При цьому перебіг захворювання батьків характеризувався вираженим ураженням бронхолегеневої системи, що потребувало диференціювання захворювання з SARS-CoV-2. 59 дітей інфікували 72 дорослі людини (своїх батьків), таким чином репродуктивний показник у сім'ях становив 72:59=1,22.

\section{Висновки}

1. В умовах великого міста діти можуть бути резервуаром $\mathrm{i}$ основним переносником інфекції SARS-CoV-2.

2. Соціальне дистанціювання, ефективне поза домом, складно здійснити в умовах сім'ї, що є обтяжливим фактором при веденні безсимптомних пацієнтів. Батьки дітей молодшого віку захворіли у більшості випадків повітряно-крапельним шляхом поширення інфекції, носячи хворих дітей на руках.

3. Стандартна противірусна терапія (інгібітори РНК вірусів, симптоматична терапія) зумовила повне одужання. 
4. Через 7-9 днів від початку захворювання ускладнень перебігу коронавірусної інфекції не відзначали в жодної дитини.

5. Висока вартість ПЛР-діагностики обмежує своєчасне проведення тесту на ранніх етапах захворювання.

6. Чим вище обтяженість дорослих батьків коморбідними і поліморбідними хворобами, тим частіше виявляли пневмонію, аритмію й геморагічну енцефалопатію.

\author{
Конфлікт інтересів: відсутній. \\ Conflict of interests: the authors declare no conflict of interests.
}

\section{Список використаної литератури/References:}

1. McIntosh K., Hirsch M.S., Bloom A. (2021) COVID-19: Epidemiology, virology, and prevention (https://www.uptodate.com/contents/covid-19-epidemiology-virology-and-prevention).

2. Johns Hopkins University and Medicine (2021) COVID-19 Dashboard by the Center for Systems Science and Engineering (CSSE) at Johns Hopkins University (JHU) (https://coronavirus.jhu. edu/map.html).

3. World Health Organization (2021) Coronavirus Disease (COVID-19): Frequently Asked Questions (https://www.who.int/ru/emergencies/diseases/novel-coronavirus-2019/advice-forpublic/q-a-coronaviruses).

4. World Health Organization (2020) Questions and answers: Similarities and Differences between COVID-19 and Influenza Pathogens (https://www.who.int/ru/ news-room/q-a-detail/q-a-similarities-and-differences-covid-19-and-influenza).

5. World Health Organization (2020) Transmission of SARS-CoV-2: implications for infection prevention precautions (https://www.who.int/publications/i/item/modes-of-transmissionof-virus-causing-covid-19-implications-for-ipc-precaution-recommendations).

6. Centers for Disease Control and Prevention (2020) Public Health Guidance for CommunityRelated Exposure (https://www.cdc.gov/coronavirus/2019-ncov/php/public-health-recommendations.html).

7. Stringhini S., Wisniak A., Piumatti G. et al. et al. (2020) Seroprevalence of anti-SARS-CoV-2 IgG antibodies in Geneva, Switzerland (SEROCoV-POP): a population-based study. Lancet, 396(10247):313-319. D0l:https://doi.org/10.1016/50140-6736(20)31304-0.

8. Centers for Disease Control and Prevention (2020) Commercial Laboratory Seroprevalence Surveys (https://www.cdc.gov/coronavirus/2019-ncov/cases-updates/commercial-labsurveys.html).

9. Havers F.P., Reed C., Lim T. et al. (2020) Seroprevalence of Antibodies to SARS-CoV-2 in 10 Sites in the United States, March 23 - May 12, 2020. JAMA Intern. Med. doi: 10.1001/jamainternmed.2020.4130.

10. Meyerowitz E.A., Richterman A., Gandhi R.T., Sax P.E. (2020) Transmission of SARS-CoV-2: A Review of Viral, Host, and Environmental Factors. Ann. Intern. Med. https://doi.org/10.7326/ M20-5008.

\section{Відомості про авторів:}

Подгорна Тетяна Георгіївна — кандидат медичних наук, лікар-педіатр дитячого консультативно-діагностичного центру, Одеса, Україна.

Бірюков Віктор Сергійович — кандидат медичних наук, доцент кафедри соціальної медицини, медичного права та менеджменту Одеського національного медичного університету. Шаповалов Олексій Григорович — лікар-кардіолог дитячого консультативно-діагностичного центру, Одеса, Україна.

Кірпічова Наталія Борисівна — лікар-невролог дитячого консультативно-діагностичного центру, Одеса, Україна.

Адреса для кореспонденції:

Бірюков Віктор Сергійович

65082, Одеса, Валіховський пров., 2

E-mail:dr.viktor.biryukov@gmail.com
}

11. Chagla Z., Hota S., Khan S., Mertz D. (2020) Airborne Transmission of COVID-19. Clin. Infect. Dis. doi: 10.1093/cid/ciaa1118.

12. Klompas M., Baker M.A., Rhee Ch. (2020) Airborne Transmission of SARS-CoV-2: Theoretical Considerations and Available Evidence. JAMA. doi: 10.1001/jama.2020.12458.

13. Lu J., Gu J., Li K. et al. (2020) COVID-19 Outbreak Associated with Air Conditioning in Restaurant, Guangzhou, China, 2020. Emerg. Infect. Dis., 26(7) (https://wwwnc.cdc.gov/eid/article/26/7/20-0764_article).

14. Shen Y., Li Ch., Dong H. et al. (2020) Community Outbreak Investigation of SARS-CoV-2 Transmission Among Bus Riders in Eastern China. JAMA Intern. Med., 180(12): 1665-1671. doi: 10.1001/jamainternmed.2020.5225.

\section{Peculiarities of the epidemiology of coronavirus infection SARS- CoV-2 at the family medicine level \\ T.G. Podgornaya', V.S. Biryukov', O.G. Shapovalov', N.B. Kirpichova' \\ 'Children's Consultative and Diagnostic Center, Odessa, Ukraine ${ }^{2}$ Odessa national medical university, Odessa, Ukraine}

Abstract. A retrospective analysis the case histories of patients from 42 families ( 59 children aged $2-18$ years and 72 parents) with confirmed SARS-CoV-2 infection was carried out. In the studied contingent of children, the disease proceeded without lung damage with the usual symptom complex of acute respiratory viral infections and did not require inpatient treatment, while 53 adult family members were diagnosed with COVID-associated pneumonia were hospitalized. The data obtained may indicate a potentially manifest role of children as a reservoir and the main carrier of SARS-CoV-2 infection in a large city, as evidenced by a wave of disease among parents after $6.08 \pm 0.26$ days, while the parents showed a pronounced lesion of the bronchopulmonary system. The aggravating effect of bad habits (smoking), the presence of premorbid/polymorbid pathology on the severity clinical picture in adult patients was confirmed. Social distancing during home isolation within the family showed low efficiency, and the high cost of PCR testing had a negative impact on the timing of diagnosis.

Key words: SARS-CoV-2, family medicine, COVID-19 in children, the role of children in the transmission of SARS-CoV-2.

\section{Information about authors:}

Podgornaya Tatyana G. - Candidate of Medical Sciences, Pediatrician of the Children's Consultative and Diagnostic Center, Odessa, Ukraine.

Biryukov Viktor S. - Candidate of Medical Sciences, Associate Professor of the Department of Social Medicine, Medical Law and Management, ONMedU.

Shapovalov Alexey G. — doctor-cardiologist of the Children's Consultative and Diagnostic Center, Odessa, Ukraine.

Kirpichova Nataliya B. — doctor-neurologist of the Children's Consultative and Diagnostic Center, Odessa, Ukraine.

Address for correspondence:

Viktor Biryukov

65082, Odessa, Valikhovsky Lane, 2

E-mail: dr.viktor.biryukov@gmail.com 